\title{
TOPSIS and SLR methods on the Decision Support System for Selection the Management Strategies of Funeral Land
}

\author{
Yayang Eluis Bali Mawartika*1, Azhari SN ${ }^{2}$, Agus Sihabuddin ${ }^{3}$ \\ ${ }^{1}$ Program Studi S2 Ilmu Komputer FMIPA UGM, Yogyakarta, Indonesia \\ ${ }^{2}$ Departemen Ilmu Komputer dan Elektronika, FMIPA UGM, Yogyakarta, Indonesia \\ e-mail: *11 yayang.e@mail.ugm.ac.id, ${ }^{2}$ arisn@ugm.ac.id, ${ }^{3}$ a_sihabudin@ugm.ac.id
}

\begin{abstract}
Abstrak
Lahan pemakaman merupakan salah satu fasilitas umum yang harus disediakan oleh Pemerintah Daerah untuk mendukung kegiatan masyarakat. Kebutuhan akan lahan pemakaman di Kota Lubuklinggau terus bertambah sedangkan luas lahan pemakaman yang tersedia semakin berkurang, hal ini dikarenakan jumlah kematian penduduk terus meningkat setiap tahunnya. Meramalkan luas lahan pemakaman yang tersedia untuk tahun yang akan datang serta menerapkan strategi pengelolaan lahan pemakaman dapat mengatasi permasalahan kebutuhan lahan pemakaman. Peramalan ketersediaan lahan pemakaman dalam penelitian ini menggunakan metode Simple Linear Regression. Metode TOPSIS digunakan untuk memilih strategi pengelolaan lahan pemakaman. Peramalan menggunakan dua variabel yaitu variabel jumlah kematian penduduk dan variabel jumlah luas lahan pemakaman dalam periode 5 tahun terakhir. Hasil peramalan akan dijadikan salah satu kriteria penilaian dalam sistem pendukung keputusan pemilihan strategi pengelolaan lahan pemakaman. Alternatif strategi pengelolaan lahan pemakaman yang akan diterapkan dan dinilai sesuai dengan Peraturan Daerah Kota Lubuklinggau. Nilai tertinggi dari hasil akhir sistem akan dijadian sebagai rekomendasi pemilihan strategi pengelolaan lahan pemakaman.
\end{abstract}

Kata kunci-SPK, Peramalan, Pengelolaan Lahan Pemakaman, TOPSIS, SLR

\begin{abstract}
The funeral land is one of the public facilities that must be provided by Local Government to support community activities. The need for funeral land in Lubuklinggau continues to increase while the availability of funeral land is decreasing, this is because the number of deaths of the population continues to increase every year. Forecasting the land availability of funeral for the coming year and applying the management strategies of funeral land can overcome the needs of the cemetery. Forecasting the land availability of funeral using Simple Linear Regression. TOPSIS to choose the management strategies of funeral land. Forecasting uses two variables that are the variable number of the population deaths and the variable amount of funeral land in the last 5 years. Forecasting results will be used as one of the assessment criteria in the decision support system for selection of the management strategies of funeral land. The alternative of the funeral management strategy that will be applied and assessed in accordance with Local Regulation of Town of Lubuklinggau. The highest value of the end result of the system will be used as a recommendation for the selection of management strategies.
\end{abstract}

Keywords-DSS, Forecasting, Management of Funeral Land, TOPSIS, SLR

Received Oct 18 ${ }^{\text {th }}, 2018 ;$ Revised Jan 28 ${ }^{\text {th }}, 2019 ;$ Accepted April $28^{\text {th }}, 2019$ 


\section{INTRODUCTION}

Lubuklinggau is a city at the level of the westernmost district of the province of South Sumatra. The area of the city of Lubuklinggau is based on Law No. 7 of 2001 covering an area of $401.50 \mathrm{~km}^{2}$ or 40,150 ha covering 8 sub-districts and 72 villages. Lubuklinggau City has a population of 222,870 people [1]. The level of population density in the city of Lubuklinggau is increasing every year. The increase in population density in an area has an impact on increasing land requirements, while the available land has diminished due to the rapid population growth. Increasing land requirements will cause problems in providing land for public facilities. One of the public facility that is a problem in the City of Lubuklinggau is funeral land because the slow sea funeral land will be full while the burial ground is limited and cannot continue to accommodate the deceased population in the future.

The Lubuklinggau City Population and Civil Registration Service project the number of deaths per year from 2018-2035 to increase every year. Meanwhile, according to data from the Lubuklinggau City Housing and Settlement Agency, the area of the cemetery in the city of Lubuklinggau in 2015 was $3,386,881 \mathrm{~m} 2$ with grave conditions that had begun to be filled in several locations and feared that the burial land would be exhausted and could not accommodate the population who died.

Limitations of land for the funeral can cause problems if management of the cemetery is not immediately carried out. Therefore, it is necessary to implement a funeral land management strategy to overcome the limitations of the cemetery land. To choose the right funeral land management strategy based on assessment criteria, a decision support system is needed in choosing a funeral land management strategy.

The amount of funeral land availability is a factor behind the need for the implementation of funeral land management strategies to overcome the limitations of funerals land in the future, but at this time information on the number of available burial grounds is not yet known, so it is not known how much the available funeral area for the year will come that requires the implementation of the funeral land management strategy. Therefore, before choosing a funeral land management strategy, first calculate how much funeral land is available for the coming year by applying the forecasting system for the funeral land availability. With this forecasting system, decision makers can find out how much funeral land is available so that they can choose the right funeral land management strategy based on the results of the forecasting area of the cemetery.

Several studies have been conducted regarding the application of the TOPSIS method and the application of the Simple Linear Regression method. The research included: uses the TOPSIS method to get drugs that match the type of disease [2], to get the best employee ranking [3], to choose student street vendors [4], to determine the priority of home conditions [5], to design a novel performance evaluation model [6], to choose freshwater fish farming research [7]. Research [8] uses the Linear Regression method to forecast electricity prices for the future. Research [9] uses the Linear Regression method to predict future crimes.

In this study forecasting with Simple Linear Regression is used to predict the availability of funeral land, the forecasting results will be used as one of the decision support criteria for choosing a funeral land management strategy. Furthermore, implementing a decision support system using the TOPSIS method is expected to assist decision makers in choosing a funeral land management strategy.

\section{METHODS}

\subsection{Literature Review}

2. 1.1 Decision Support System

Decision support system is used as a tool for decision-makers to expand the capabilities

IJCCS Vol. 13, No. 2, April 2019: $167-176$ 
of decision makers, but not to replace the judgment of decision makers. DSS is intended for decisions that require assessment or for decisions that cannot be supported by the algorithm at all. SPK is expanding rapidly, from just a personal support tool to a commodity that is used together [10].

\subsubsection{Technique for Order Preference by Similarity to Ideal Solution (TOPSIS)}

The principle of TOPSIS is that the chosen plan must be as close as possible to the positive ideal solution and as far as possible from the negative ideal solution. TOPSIS will rank alternatives based on the priority of the relative proximity value of an alternative to a positive ideal solution. The alternatives that have been ranked are then used as a reference for decisionmakers to choose the best solution they want. This method is widely used to solve practical decisions. This is because the concept is simple and easy to understand, the computation is efficient, and has the ability to measure the relative performance of decision alternatives [10].

The calculation steps in the TOPSIS method are as follows:
a. Make a normalized decision matrix
b. Make a weighted normalized decision matrix
c. Determine positive ideal solutions and negative ideal solutions
d. Determine the distance between the values of each alternative with positive ideal solutions and negative ideal solutions
e. Determine preference values for each alternative

\subsubsection{Make a Normalized Decision Matrix}

TOPSIS requires performance ratings for each alternative on each normalized criterion. The normalized matrix is formed from equation (1) and the normalized matrix form in equation (2).

$$
\begin{aligned}
& r_{i j}=\frac{x_{i j}}{\sqrt{\sum_{i=1}^{m} x_{i j}^{2}}} \\
& R=\left[\begin{array}{llll}
r_{11} & r_{12} & \ldots & r_{1 n} \\
r_{21} & r_{22} & \ldots & r_{2 n} \\
r_{m 1} & r_{m 2} & \ldots & r_{m n}
\end{array}\right]
\end{aligned}
$$

Clause:

$$
\begin{aligned}
& R=\text { Normalized matrix } \\
& r_{i j}=\text { The value element of the normalized matrix } \\
& x_{i j}=\text { Element values for each criterion or sub-criteria of alternatives } \\
& m=\text { Alternative number } \\
& n=\text { Number of criteria or subcriteria }
\end{aligned}
$$

\subsubsection{Make a Normalized Decision Matrix Weighted}

Equation (3) is used to calculate the normalized weight rating and the normalized matrix form is weighted in equation (4).

$$
\begin{aligned}
& y_{i j}=w_{j} r_{i j} \\
& Y=\left[\begin{array}{lllll}
w_{1} r_{11} & w_{2} r_{12} & w_{3} r_{13} & \ldots & w_{n} r_{1 n} \\
w_{1} r_{m 1} & w_{2} r_{m 2} & w_{3} r_{m 3} & \ldots & w_{4} r_{m 4}
\end{array}\right]
\end{aligned}
$$

Clause:

$$
\begin{aligned}
& Y=\text { The normalized matrix is weighted } \\
& y_{i j}=\text { The value element of the normalized matrix is weighted } \\
& w_{j}=\text { The preference weight value for each criterion or subcriteria } \\
& m=\text { Alternative number } \\
& n=\text { Number of criteria or subcriteria }
\end{aligned}
$$




\subsubsection{Determine Positive Ideal Solutions and Negative Ideal Solutions}

Positive ideal solutions and negative ideal solutions can be determined based on the normalized weight rating of equation (3). It should be noted the conditions in equation (5) and equation (6) in order to calculate the value of an ideal solution by first determining whether it is a benefit or a cost.

$$
\begin{aligned}
& A^{+}=\left(y_{1}^{+}, y_{2}^{+}, \ldots, y_{n}^{+}\right) \\
& A^{-}=\left(y_{1}^{-}, y_{2}^{-}, \ldots, y_{n}^{-}\right)
\end{aligned}
$$

Requirement:

$$
\begin{aligned}
& y_{i}^{+}=\left\{\begin{array}{c}
\max y_{i j}, i f j \text { is the benefit attribute } \\
\min _{i j},{ }_{i j} j \text { is the cost attribute }
\end{array}\right. \\
& y_{i}^{-}=\left\{\begin{array}{l}
\text { min } y_{i j}, \text { if } j \text { is the cost attribute } \\
\max _{i j}, \text { if } j \text { is the benefit attribute }
\end{array}\right.
\end{aligned}
$$

2.1.2.4 Determine The Distance between The Values of Each Alternative with Positive Ideal Solutions and Negative Ideal Solutions

Alternative distance $\left(\mathrm{D}_{\mathrm{i}}^{+}\right)$with the positive ideal solution is formulated in equation (7).

$$
D_{i}^{+}=\sqrt{\sum_{j=1}^{n}\left(y_{i j}^{+}-y_{j}\right)^{2}}
$$

Clause:

$i=$ worth 1 to $m$ is a lot of alternatives

$n=$ Number of criteria or subcriteria

Alternative distance $\left(D_{i}^{-}\right)$with the negative ideal solution is formulated in equation (8).

$$
D_{i}^{-}=\sqrt{\sum_{j=1}^{n}\left(y_{j}-y_{i j}^{-}\right)^{2}}
$$

Clause:

$i=$ worth 1 to $m$ is a lot of alternative

$n=$ Number of criteria or subcriteria

\subsubsection{Determine Preference Values for Each Alternative}

Preference values $(\mathrm{Vi})$ for each alternative is formulated in equation (9).

$$
V i=\frac{D_{i}^{-}}{D_{i}^{-}+D_{-}^{\ddagger}}
$$

Clause:

$i=$ worth 1 to $m$ is a number of alternative

$D=$ alternative distance

\subsubsection{Forecasting}

Forecasting is the process of predicting the future. Forecasting is a combination of art and science in estimating the conditions in the future, by projecting past data into the future using mathematical models and subjective estimates [11].

\subsubsection{Linear Regression Analysis}

One forecasting model included in the associative forecasting method is linear regression analysis. Regression analysis is a mathematical equation that allows predicting the values of a variable not free from the values of one or more independent variables [12]. Linear regression consists of two, namely simple linear regression with one independent variable and 
one related variable, and multiple linear regression with several independent variables and one related variable.

\subsubsection{Simple Linear Regression}

Simple Linear Regression is a regression equation where the independent variables are scalar. Simple linear regression analysis is used to determine the effect of one independent variable on one related variable [12].

The calculation steps for the Simple Linear Regression method are as follows:

a. Identify the cause $(x)$ and effect variables $(y)$

b. Calculate $x^{2}, x y$ and total respectively

c. Calculate the value of $b$

d. Calculate the value of $a$

e. Calculate the forecasting of the causal variables against the variables due to regression

The regression equation used in Simple Linear Regression is equation (10). Whereas to find the value of a using equation (11) and the value of $b$ using equation (12).

$$
\begin{aligned}
& y^{\prime}=a+b x \\
& a=\frac{\sum y-b \sum x}{n} \\
& b=\frac{n \sum(x, y)-\sum x \sum y}{n \sum x^{2}-\left(\sum x\right)^{2}}
\end{aligned}
$$

Clause:

$$
\begin{aligned}
& y=\text { Dependent variable (cause variable) } \\
& a=\text { Constant } \\
& b=\text { variable coefficient } X \\
& x=\text { Independent variable (effect variable) }
\end{aligned}
$$

\subsection{System Architecture}

The system architecture used in decision support systems for the selection of funeral land management strategies based on the results of forecasting the availability of funeral land is a relationship that can be seen between the components related to the system. The software used to process the data is MySQL, TOPSIS method is used as a method for choosing a funeral land management strategy, the user interface subsystem used is a web-based interface using PHP, and the user who will use the system is the admin and chairman. The system architecture can be seen in Figure 1.

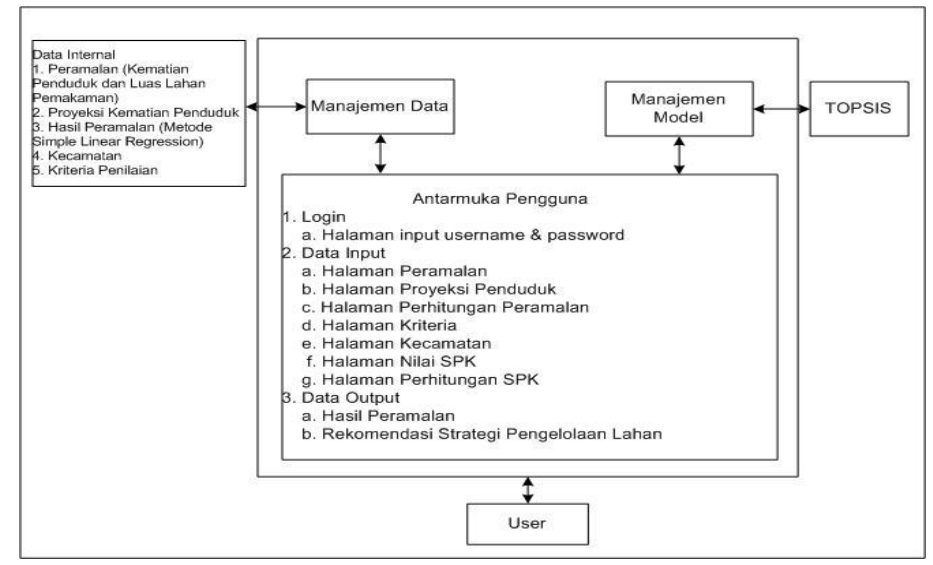

Figure 1 System Architecture of Decision Support System 


\section{RESULTS AND DISCUSSION}

\subsection{Calculation of Forecasting of Funeral Land Availability}

The forecasting process is the first step carried out in the workflow of the decision support system for the selection of funeral land management strategies based on the results of forecasting the availability of funeral land. Forecasting the availability of funeral land using the Simple Linear Regression method.

The Simple Linear Regression method is one of the forecasting methods that performs forecasting by knowing the influence of the causal variables on the consequent variables. The variables used in forecasting the availability of funeral land are the number of deaths as the cause variable $(X)$ and the size of the funeral area as a consequence variable $(Y)$. From these two variables, an analysis of the effect of population mortality on the area of the cemetery will be carried out, which results in a large number of available funeral grounds for the coming year.

The data used in forecasting the funeral land availability are population mortality data and funeral land area data in the last 5 years to predict the availability of funeral land in the next 5 years, and in the example calculation below forecasting is carried out in Lubuklinggau Barat I sub-district, forecasting data is presented in Table 1.

Table 1 Forecasting Data

\begin{tabular}{|c|c|c|c|}
\hline Sub-District Name & Year & Number of Deaths $(X)$ & Funeral Land (ha) $(Y)$ \\
\hline \multirow{4}{*}{ Lubuklinggau Barat I } & 2013 & 93 & 81,8679 \\
\cline { 2 - 4 } & 2014 & 118 & 81,6644 \\
\cline { 2 - 4 } & 2015 & 183 & 81,4609 \\
\cline { 2 - 4 } & 2016 & 244 & 81,2574 \\
\cline { 2 - 4 } & 2017 & 279 & 81,0537 \\
\hline
\end{tabular}

Based on Table 1 it is known that the cause variable $(X)$ is the number of deaths, and the consequent variable $(Y)$ is the funeral land, the next step is to calculate $x^{2}, x y$ and the total of each. The variable $x^{2}$ is obtained from the process of lifting data on the variable $x$, while the variable $x y$ is obtained from the process of multiplying the data on the variable $x$ with the variable $y$. After getting the calculation results from all of these variables, then do the total sum of each variable. The results of variable calculations are shown in Table 2.

Table 2 Variable Calculation

\begin{tabular}{|c|r|r|r|r|}
\hline Year & $X$ & $y$ & \multicolumn{1}{|c|}{$x^{2}$} & \multicolumn{1}{|c|}{$X y$} \\
\hline 2013 & 93 & 81,8679 & 8649 & 7613,7147 \\
\hline 2014 & 118 & 81,6644 & 13924 & 9636,3992 \\
\hline 2015 & 183 & 81,4609 & 33489 & 14907,3447 \\
\hline 2016 & 244 & 81,2574 & 59536 & 19826,8056 \\
\hline 2017 & 279 & 81,0537 & 77841 & 22613,9823 \\
\hline Total $\left(\sum\right)$ & $\mathbf{9 1 7}$ & $\mathbf{4 0 7 , 3 0 4 3}$ & $\mathbf{1 9 3 4 3 9}$ & $\mathbf{7 4 5 9 8 , 2 4 6 5}$ \\
\hline & $\left(\sum \boldsymbol{x}\right)^{\mathbf{2}}=\mathbf{8 4 0 8 8 9}$ & & & \\
\hline
\end{tabular}

The next step is to calculate the value of $a$ and $b$ using equation (11) and equation (12) by entering the calculation results from Table 2 . The results of calculating a and $b$ values are presented in Table 3.

$$
\begin{aligned}
\boldsymbol{b} & =\frac{\boldsymbol{n} \sum(\boldsymbol{x} \boldsymbol{y})-\sum x \sum \boldsymbol{y}}{\boldsymbol{n} \sum \boldsymbol{x}^{2}-\left(\sum x\right)^{2}} \\
& =\frac{5(74598,2465)-(917)(407,3043)}{5(193439)-(840889)} \\
& =\frac{372991,233-373498,0431}{967195-840889} \\
& =\frac{-506,8106}{126306} \\
& =-0,0040126 \\
\boldsymbol{a} & =\frac{\sum y-b \sum x}{n}
\end{aligned}
$$

IJCCS Vol. 13, No. 2, April 2019: $167-176$ 


$$
\begin{aligned}
& =\frac{407,3043-(-0,0040126)(917)}{5} \\
& =\frac{407,3041-(-3,67717)}{5} \\
& =\frac{410,98147}{5} \\
& =82,196294
\end{aligned}
$$

Table 3 Results of Calculation of Value $a$ and Value $b$

\begin{tabular}{|l|c|c|}
\hline \multicolumn{1}{|c|}{ Sub-District Name } & Value of $a$ & Value of $b$ \\
\hline Lubuklinggau Barat I & 82,196294 & $-0,0040126$ \\
\hline
\end{tabular}

Based on Table 3 it is known that the value of $a$ is 82.196294 and the value of $b$ is -0.0040126 , the value of $a$ and the value of $b$ will be used in the regression calculation process to predict the availability of funeral land using equation (10).

$\boldsymbol{Y}^{\prime}=\boldsymbol{a}+\boldsymbol{b} \boldsymbol{X}$

$Y=82,196294+(-0,00401) X$

Variable $X$ is the population mortality for the coming year. The population mortality rate for the coming year is obtained from the data of the projected mortality rate of the population of Lubuklinggau City. Death projection data are presented in Table 4.

Table 4 Death Projection Data

\begin{tabular}{|c|c|c|}
\hline Sub-District Name & Year & Projected Dearh Rate \\
\hline Lubuklinggau Barat I & 2018 & 333 \\
\hline & 2019 & 382 \\
\hline & 2020 & 432 \\
\hline & 2021 & 482 \\
\hline & 2022 & 532 \\
\hline
\end{tabular}

Forecasting the variable causes with variables due to the forecasting process is: if the population mortality rate in Lubuklinggau Barat I sub-district in 2018 totaled 333 people, what is the area of burial land remaining for 2018 ? The forecasting results are presented in Table 5.

$\boldsymbol{Y}^{\prime}=\boldsymbol{a}+\boldsymbol{b} \boldsymbol{X}$

$Y=82,196294+(-0,00401)(333$ jiwa $)$

$Y=82,196294+(-1,33533)$

$Y=80,860964$ (hektare)

Table 5 Forecasting Results

\begin{tabular}{|c|c|c|}
\hline Sub-District Name & Year & Funeral Land Forecasting Results \\
\hline Lubuklinggau Barat I & 2018 & 80,8610 \\
\cline { 2 - 3 } & 2019 & 80,6645 \\
\cline { 2 - 3 } & 2020 & 80,4640 \\
\cline { 2 - 3 } & 2021 & 80,2635 \\
\cline { 2 - 3 } & 2022 & 80,0630 \\
\hline
\end{tabular}

After the forecasting process is complete, the results of forecasting the funeral land in Table 5 are used in the assessment of the decision support system to choose the funeral land management strategy on the forecasting outcome criteria.

\subsection{TOPSIS Calculation}

After the forecasting process is complete, the next step is to calculate the decision support system to choose a funeral land management strategy using the TOPSIS method. In this study alternative or management strategies for the funeral land used are based on the Lubuklinggau City Regional Regulation Number 9 of 2010 which implements a management strategy by carrying out funeral overlap systems, contract systems, structuring tomb plots and opening new funeral lands. 
The number of criteria used is 6 criteria. In the calculation example below, the assessment was conducted in Lubuklinggau Barat I Subdistrict, the value entered by the decision maker in this case, the funeral cation is presented in Table 6, while in Table 7 is the weight of each criterion.

Table 6 Alternative Value in Each Criteria

\begin{tabular}{|c|l|l|c|c|c|c|}
\hline & \multicolumn{1}{|c|}{$\mathrm{C} 1$} & $\mathrm{C} 2$ & $\mathrm{C} 3$ & $\mathrm{C} 4$ & $\mathrm{C} 5$ & $\mathrm{C} 6$ \\
\hline $\mathrm{A} 1$ & 41000000000 & 180000 & 213542 & 10 & 10 & 10 \\
\hline $\mathrm{A} 2$ & 250000 & 50000 & 424303 & 5 & 5 & 5 \\
\hline $\mathrm{A} 3$ & 300000 & 275000 & 210575 & 1 & 5 & 1 \\
\hline A4 & 20354000000 & 150000 & 102800 & 5 & 5 & 1 \\
\hline
\end{tabular}

Code Statement

A1 New Land

A2 Overlapping System

A3 Contract System

A4 Graveyard Arrangement

C1 Implementation Cost
Code

$\mathrm{C} 2$

$\mathrm{C} 3$

$\mathrm{C} 4$

C5

C6
Statement

Retribution Cost

Carrying Power Effectiveness

Environmental Impact

Custom

Community Psychology

Table 7 Weight of Each Criteria

\begin{tabular}{|c|c|c|c|c|c|}
\hline C1 & C2 & C3 & C4 & C5 & C6 \\
\hline 0.18 & 0.12 & 0.4 & 0.15 & 0.0675 & 0.0825 \\
\hline
\end{tabular}

Based on the steps to calculate the TOPSIS method, the first step is to calculate the normalized matrix using equation (1).

Examples of normalization of alternative values for criterion 1 (implementation costs):

$\frac{x_{i f}}{\sqrt{\sum_{i=1}^{m} x_{i f}^{2}}}$ Maka $r_{11}=\frac{41000000000}{45774286626}=0,895699377$

The normalization results of the four alternatives are shown in Table 8.

Table 8 Normalization Results

\begin{tabular}{|c|c|c|c|c|c|c|}
\hline & C1 & C2 & C3 & C4 & C5 & C6 \\
\hline A1 & 0,895699377 & 0,493521266 & 0,403165788 & 0,813788459 & 0,755928946 & 0,887356509 \\
\hline A2 & 0,000005462 & 0,137089241 & 0,801081067 & 0,406894229 & 0,377964473 & 0,443678255 \\
\hline A3 & 0,000006554 & 0,753990823 & 0,397564112 & 0,081378846 & 0,377964473 & 0,088735651 \\
\hline A4 & 0,444660125 & 0,411267722 & 0,194085674 & 0,406894229 & 0,377964473 & 0,088735651 \\
\hline
\end{tabular}

The next step is to calculate the normalized weighted matrix using equation (3). The weight normalization matrix is the result of the weight of the predetermined criteria with the value obtained from the calculation of the normalization matrix.

An example of normalization is weighted for alternatives $1 *$ weights criteria:

$y_{i j}=w_{j} r_{i j}=\mathrm{Y}_{11}=\mathrm{W}_{1} \mathrm{r}_{11}=(0,18)(0,895699377)=0,161225888$

Table 9 shows the results of the multiplication between normalization values in Table 8 with the weighting criteria in Table 7.

Table 9 Normalized Weighted Results

\begin{tabular}{|c|c|c|l|c|c|c|}
\hline & C1 & C2 & \multicolumn{1}{c|}{ C3 } & C4 & C5 & C6 \\
\hline A1 & 0,161225888 & 0,059222552 & 0,161266315 & 0,122068269 & 0,051025204 & 0,073206912 \\
\hline A2 & 0,000000983 & 0,016450709 & 0,320432427 & 0,061034134 & 0,025512602 & 0,036603456 \\
\hline A3 & 0,000001180 & 0,090478899 & 0,159025645 & 0,012206827 & 0,025512602 & 0,007320691 \\
\hline A4 & 0,080038822 & 0,049352127 & 0,07763427 & 0,061034134 & 0,025512602 & 0,007320691 \\
\hline
\end{tabular}

After getting weighted normalization, the next step is to calculate positive ideal solutions and negative ideal solutions. To find positive ideal solutions using equation (5) and to find negative ideal solutions using equation (6).

Example calculation process:

If Criteria $=$ Benefit

IJCCS Vol. 13, No. 2, April 2019: $167-176$ 
Then the positive ideal solution $(\mathrm{A}+)=$ the maximum value of the four alternatives in each criteria.

$\mathrm{A}+($ Carrying Power Effectiveness $) \quad=\operatorname{MAX}(0,161266315 ; 0,320432427 ; 0,159025645$;

$$
=0,320432427
$$

If Criteria $=$ Cost

$0,07763427)$

Then the positive ideal solution $(\mathrm{A}+)=$ the minimum value of the four alternatives in each criteria.

$\mathrm{A}+($ Implementation Cost $) \quad=\operatorname{MIN}(0,161225888 ; 0,000000983 ; 0,000001180 ;$

If Criteria $=$ Benefit

Then the negative ideal solution (A-) = the minimum value of the four alternatives in each criteria.

A- (Carrying Power Effectiveness) = MIN (0,161266315; 0,320432427; 0, 159025645;

$0,080038822)$

$=0,000000983$

If Criteria $=$ Cost

Then the negative ideal solution (A-) criteria.

A- (Implementation Cost) $0,07763427)$

$=0,07763427$

$=$ the maximum value of the four alternatives in each

$=\operatorname{MAX}(0,161225888 ; 0,000000983 ; 0,000001180 ;$ $0,080038822)$

$=0,161225888$

The results of the calculation of the determination of positive ideal solutions and negative ideal solutions in each criterion are presented in Table 10.

Table 10 Positive Ideal Solutions and Negative Ideal Solutions

\begin{tabular}{|c|c|c|c|c|c|c|}
\hline & C1 & C2 & C3 & C4 & C5 & C6 \\
\hline A+ & 0,000000983 & 0,090478899 & 0,320432427 & 0,012206827 & 0,051025204 & 0,073206912 \\
\hline A- & 0,161225888 & 0,016450709 & 0,07763427 & 0,122068269 & 0,025512602 & 0,007320691 \\
\hline
\end{tabular}

After getting the positive ideal solution and the negative ideal solution, the next step is to determine the alternative distance $(\mathrm{Di}+)$ with the positive ideal solution using equation $(7)$, while the alternative distance (Di-) with the negative ideal solution uses equation (8).

Example calculation process:

Distance is a positive ideal solution for alternative $1(\mathrm{D}+)$

$$
\begin{aligned}
& \mathrm{D} 1+=\sqrt{\begin{array}{l}
(0,000000983-0,161225888)^{2}+(0,090478899-0,059222552)^{2}+ \\
(0,320432427-0,161266315)^{2}+(0,012206827-0,122068269)^{2}+ \\
(0,051025204-0,051025204)^{2}+(0,073206912-0,073206912)^{2}
\end{array}} \\
& =0,253719957
\end{aligned}
$$

Distance is the ideal negative solution for alternative 1 (D-)

$$
\begin{aligned}
& \text { D1- }= \sqrt{\begin{array}{c}
(0,161225888-0,161225888)^{2}+(0,059222552-0,016450709)^{2}+ \\
(0,161266315- \\
0,07763427)^{2}+(0,1222068269-0,122068269)^{2}+ \\
+(0,051025204-0,025512602)^{2} \\
+(0,073206912-0,007320691)^{2}
\end{array}} \\
&=0,117539936
\end{aligned}
$$

The results of the overall calculations obtained are presented in Table 11.

Table 11 Alternative Distance Positive Ideal Solutions and Negative Ideal Solutions

\begin{tabular}{|l|r|r|}
\hline \multicolumn{1}{|c|}{ Alternative } & D+ & \multicolumn{1}{c|}{ D- } \\
\hline New Land & 0,253719957 & 0,117539936 \\
\hline Overlapping System & 0,099272276 & 0,29921073 \\
\hline Contract System & 0,176193178 & 0,22398141 \\
\hline Graveyard Arrangement & 0,272808367 & 0,106766139 \\
\hline
\end{tabular}

The final step is to calculate the preference value for each alternative using equation (9). 
Example calculation process:

Alternative preference value $1=V_{\text {alternatif } 1}=\frac{0,117589986}{0,117589936+0,258719957}=0,316597451$

Preference values for each alternative are presented in Table 12.

Table 12 Value of each Alternative Preference

\begin{tabular}{|l|r|}
\hline \multicolumn{1}{|c|}{ Alternative } & Preference Value \\
\hline New Land & 0,316597451 \\
\hline Overlapping System & 0,750874506 \\
\hline Contract System & 0,559709228 \\
\hline Graveyard Arrangement & 0,281278477 \\
\hline
\end{tabular}

In Table 12, it can be seen that the alternative overlapping system has the largest value of 0,750874506 , and is followed by a contract system with a value of 0,559709228 , then a new land of 0,316597451 , and finally the grave plot arrangement of 0.281278477 . So, by using the TOPSIS method, the best funeral land management strategy for Lubuklinggau Barat I Subdistrict is to implement a overlapping system strategy.

\section{CONCLUSIONS}

The TOPSIS method can be used to assist decision makers in choosing a funeral land management strategy based on the results of forecasting the availability of funeral land. Simple Linear Regression method can be used in the forecasting process of the availability of funeral land, the increasing mortality rate of the population has resulted in diminishing funeral land.

\section{REFERENCES}

[1] Badan Pusat Statistik Kota Lubuklinggau, 2016. Kependudukan. https://lubuklinggaukota.bps.go.id.

[2] A. A. Larasati, A. H. Setyaningrum, and L. K. Wardhani, "Development Decision Support System of Choosing Medicine using TOPSIS Method," Int. Conf. Inf. Commun. Technol. Muslim World 6th, pp. 160-165, 2016.

[3] M. A. Budhi and R. Wardoyo, "Group Decision Support System Determination Of Best Employee Using Topsis And Borda," IJCCS (Indonesian J. Comput. Cybern. Syst., vol. 11, no. 2, p. 165, 2017.

[4] D. N. Ilham and S. Mulyana, "Sistem Pendukung Keputusan Kelompok Pemilihan Tempat PKL mahasiswa dengan Menggunakan Metode AHP dan Borda," IJCCS (Indonesian J. Comput. Cybern. Syst., vol. 11, no. 1, p. 55, 2017.

[5] A. A. Chamid, "Penerapan Metode TOPSIS untuk Menentukan Prioritas Kondisi Rumah," Simetris, vol. 7, no. 2, pp. 537-544, 2016.

[6] M. Shaverdi, I. Ramezani, R. Tahmasebi, and A. A. A. Rostamy, "Combining Fuzzy AHP and Fuzzy TOPSIS with Financial Ratios to Design a Novel Performance Evaluation Model,” Int. J. Fuzzy Syst., vol. 18, no. 2, pp. 248-262, 2016.

[7] H. B. Lumentut and S. Hartati, "Sistem Pendukung Keputusan untuk Memilih Budidaya Ikan Air Tawar Menggunakan AF-TOPSIS," IJCCS (Indonesian J. Comput. Cybern. Syst., vol. 9, no. 2, pp. 197-206, 2015.

[8] V. Bianco, O. Manca, and S. Nardini, "Electricity consumption forecasting in Italy using linear regression models," Energy, vol. 34, no. 9, pp. 1413-1421, 2009.

[9] M. A. Awal, J. Rabbi, S. I. Hossain, and M. M. A. Hashem, "Using linear regression to forecast future trends in crime of Bangladesh," 2016 5th Int. Conf. Informatics, Electron. Vision, ICIEV 2016, pp. 333-338, 2016.

[10] E. Turban, J. E. Aronson, and T.-P. Liang, "Decision Support Systems and Intelligent System Edisi 7 Jilid 1," Andi, Yogyakarta, 2005.

[11] P. Subagyo, "Forecasting Konsep dan Aplikasi," BPFE, Yogyakarta, 2013.

[12] Rohmad and Supriyanto, "Pengantar Statistika Panduan Praktis Bagi Pengajar dan Mahasiswa," Kalimedia, Yogyakarta, 2015.

IJCCS Vol. 13, No. 2, April 2019 : $167-176$ 